Economic and Environmental Geology

Research Paper

\title{
Collapse Type and Processes of the Geumosan Caldera in the Southern Gumi, Korea
}

\author{
Sang Koo Hwang ${ }^{1}$, Young Woo Son ${ }^{2}$, Seung Hwan Seo ${ }^{3}$, Weon-Seo Kee ${ }^{4, *}$ \\ ${ }^{1}$ Department of Earth and Environmental Sciences, Andong National University, Andong 36729, Korea \\ ${ }^{2}$ Korea Water Resources Corporation, Daejeon 34350, Korea \\ ${ }^{3}$ Mungyeong City Gyeongsangbuk Province, Mungyeong 36982, Korea \\ ${ }^{4}$ Korea Institute of Korea Institute of Geoscience and Mineral Resources, Daejeon 34132, Korea \\ *Corresponding author : wskee@kigam.re.kr
}

\section{ARTICLE INFORMATION}

Manuscript received 01 December 2020

Received in revised form 14 January 2021

Manuscript accepted 18 January 2021

Available online 26 February 2021

DOI : http://dx.doi.org/10.9719/EEG.2021.54.1.35

\section{Research Highlights}

- The Cretaceous sequences in the Gumi basin are mapping into seven stratigraphic units.

- The Geumosan Tuff among them is composed of ash-flow tuffs associated with the Geumosan caldera along with ring dikes.

- The caldera, $3.5 \times 5.6 \mathrm{~km}$ wide, was formed by an asymmetric piston subsidence along the outwarding ring faults.

\begin{abstract}
The Gumi basin, situated in the mid-southeastern Yeongnam Massif, has the Cretaceous stratigraphy that is divided into Gumi Formation, andesitic rocks (Yeongamsan Tuff, Busangni Andesite), rhyolitic rocks (Obongni Tuff, Doseongul Rhyolite, Geumosan Tuff) and Intrusives (ring dikes, other dikes) in ascending order. The Geumosan Tuff is composed mostly of many ash-flow tuffs which are associated with Geumosan caldera along with the ring dikes. The caldera is outlined by ring faults and dikes and has about $3.5 \times 5.6 \mathrm{~km}$ in diameters. The intracaldera volcanics show a downsag structure that is dipped inward in their flow and welding foliations. The caldera block represent an asymmetric subsidence, which drops $350 \mathrm{~m}$ in the northern margin and $600 \mathrm{~m}$ in the southern one. Based on these data, the Geumosan caldera is geometrically classified as an asymmetric piston subsidence caldera that suggests a single caldera cycle. The caldera reflects the piston subsidence of the caldera block bounded by the outward-dipping ring faults following a voluminous eruption of magma from the chamber. The downsag in the caldera block refers to the downsagging during the initial subsidence at the same time as the full development of the bound fault. In the ring fissures following the sagging, magma was injected due to the overpressure of magma chamber caused by subsidence.
\end{abstract}

Keywords : Geumosan caldera, ash-flow tuff, ring dike, piston subsidence, downsagging

Citation: Hwang, S.K., Son, Y.W., Seo, S.H., Kee, W.-S. (2021) Collapse Type and Processes of the Geumosan Caldera in the Southern Gumi, Korea, v.54, p.35-48, doi:10.9719/EEG2021.54.1.35.

This is an Open Access article distributed under the terms of the Creative Commons Attribution Non-Commercial License (http://creativecommons.org/ licenses/by-nc/3.0) which permits unrestricted non-commercial use, distribution, and reproduction in any medium, provided original work is properly cited. pISSN 1225-7281; eISSN 2288-7962/C2021 The KSEEG. Printed by Hanrimwon Publishing Company. All rights reserved. 


\title{
연구논문
}

\section{구미 남부 금오산 칼데라의 함몰 유형과 과정}

\author{
황상구 $^{1} \cdot$ 손영우 ${ }^{2} \cdot$ 서승환 $^{3} \cdot$ 기원서 ${ }^{4, *}$ \\ ${ }^{1}$ 안동대학교 자연과학대학 지구환경과학과 \\ 2한국수자원공사 보현산댐지사 \\ ${ }^{3}$ 경상북도 문경시청 환경보호과 \\ ${ }^{4}$ 한국지질자원연구원 국토지질연구부
}

*책임저자 : wskee@kigam.re.kr

\section{요 약}

구미분지는 영남육괴의 남동 중간부에 있으며 하부로부터 백악기의 구미층, 안산암질암류(영암산응회암, 부상리안산암), 유문암 질암류(오봉리응회암, 도선굴유문암, 금오산응회암)와 관입암류(환상암맥, 기타 암맥)로 구성된다. 금오산응회암은 거의 대부분 회류응회암으로 구성되며 환상암맥과 함께 금오산 칼데라와 연관되어있다. 칼데라는 직경이 $3.5 \times 5.6 \mathrm{~km}$ 이고 환상암맥과 단 층으로 둘러싸인다. 칼데라 내부 화산암층은 유상 및 용결엽리가 대체로 칼데라 연변부에서 안쪽으로 경사되는 하향자루 구조 를 나타낸다. 칼데라 블록은 북변부에서 $350 \mathrm{~m}$, 남변부에서 $600 \mathrm{~m}$ 내려앉은 비대칭 침하를 나타낸다. 이 자료들에 의하면 금오 산 칼데라는 하나의 칼데라윤회를 암시하는 기하학적으로 비대칭 피스톤 침하 칼데라로 분류된다. 이 칼데라는 챔버로부터 마 그마의 대규모 분출에 뒤따라 외측경사 환상단층으로 경계되는 칼데라 블록의 피스톤 침하를 지시한다. 칼데라 블록에서 하향 자루는 경계 단층의 완전한 발달과 동시에 초기 침하동안 하향자루운동을 의미한다. 이 운동에 의한 벌어진 환상열극에는 침하 에 따른 마그마 과압으로 인해 마그마가 주입되어 환상암맥을 형성하였다.

주요어 : 금오산 칼데라, 회류응회암, 환상암맥, 피스톤 침하, 하향자루운동

\section{1. 서 언}

구미분지는 구미 남부에서 최고봉 $(976.5 \mathrm{~m})$ 금오산을 중심으로 김천시와 칠곡군과의 경계지역에 위치한다. 이 분지는 편마암류 및 심성암류 위에 부정합으로 타원상 분포를 보여주며, 하부의 퇴적암류와 상부의 화산암류로 구성된다. 화산암류는 이 분지의 대부분을 차지하며 분 출암류와 관입암류로 구성된다. 분출암류는 2 개 암층의 안산암질암류와 3 개 암층의 유문암질암류로 구분된다. 관 입암류는 유문암맥들로 구성되며, 특히 유문암질암류의 주변에는 환상암맥(ring dike)이 외측경사로 관입되어있 다. 이러한 양상은 환상암맥이 칼데라 함몰이라는 것을 예상케 한다. 이 암석들에 대한 층서와 구조는 후술하는 바와 같이 금오산 칼데라의 진화를 복원하기에 충분하다.

일반적으로 지질이 복잡한 화산지역에서 칼데라 구조 와 함몰 유형을 알아낸다는 것은 매우 어려움이 따른다. 왜냐하면, 최근 칼데라는 지표 노두가 제한되기 때문이 고, 반면에 침식된 고기 칼데라에서는 이의 구조와 지형 과의 관계에 대한 증거가 침식으로 제거되었기 때문이다 (Branney, 1995; Lipman, 1997). 그러나 구미분지에서 금 오산 칼데라는 칼데라내부의 깊게 절개된 단면을 제공하
여 층서와 내부관계를 연구할 수 있게 하고, Smith and Bailey(1968)가 정의한 바와 같은 칼데라의 발달단계를 연구할 기회를 제공한다. 필자들은 구미분지의 지질도를 그리고 $3.5 \times 5.6 \mathrm{~km}$ 의 금오산 칼데라의 모양과 구조를 파 악하여 이들로부터 칼데라의 함몰유형과 진화를 해석하 고자 한다. 왜냐하면 (1) 칼데라 내·외부의 화산층서가 잘 드러나 있고, (2) 칼데라의 모양이 환상암맥에 의해 이상 적으로 잘 보존되어 있으며, (3) 이들의 주요 분출사건이 칼데라 함몰과 밀접하게 연관되어있기 때문이다.

칼데라를 분류하기 위한 이전 접근방식은 대표적인 화 산에서의 분출 양식과 마그마 조성을 기반으로 칼데라 유형을 구분하는 경향이 있었다. 예로서 크라카토아 유 형, 발레스 유형, 하와이 유형 등이 있다(Macdonald, 1972; Williams and McBirney, 1979). 그러나 잘 기록된 칼데라 를 보면 입체모양과 구조들이 그 특징과 과정의 연속으 로 인해 과도기적 다양성을 가진다. 따라서 그러한 다양 한 칼데라를 별개의 유형으로 세분하는 것은 거의 쓸모 없을 뿐만 아니라 혼란만 불러일으킬 것이다. 그래서 Lipman(1997)은 기하학적으로 5개 엔드멤버로만 단순하 게 분류하고 그 과정에 관련되는 침하 입체모양과 그 결 과의 구조들을 강조하였다. 
금오산 칼데라는 기하학적 분류에서 어느 유형에 속하 는지와 어떤 침하과정을 겪었는지를 규명할 필요가 있다. 이를 위해서는 이 칼데라에 관련된 화산암류의 층서와 그 속에 포함된 암상을 해석하고 구조적인 자료를 종합 함으로써 금오산의 화산과정에 수반된 칼데라 침하과정 을 추론할 수 있다. 이 칼데라는 금오산응회암과 환상암 맥 등이 밀접하게 조합되어 있어 이들로부터 칼데라의 유형과 진화를 밝히는 데 있어 매우 적절한 곳이다.

\section{2. 지질개요}

구미분지는 경상분지와 별개로 영남육괴 남동부의 중 간에 자리 잡은 작은 분지이다. 이 분지에는 기반암 위 에 백악기 퇴적암류와 화산암류가 분포한다. 기반암은 대 부분 화강편마암류이고 이를 김천화강암이 관입하고 있 다(Kim and Lim, 1974).
구미분지에서 지질은 백악기 후엽의 퇴적암류와 화산 암류로 크게 나뉜다. 퇴적암류는 낙동층으로 기재되었지 만(Kim and $\mathrm{Lim}, 1974)$ 주로 녹회색 층이고 적갈색 층 이 협재되어 있어 층서적으로 경상분지의 어느 층에 대 비될지 문제가 있으므로 구미층으로 기재한다.

화산암류는 한반도 남동부 곳곳에서 일어났던 화산호 중에 영남호(Hwang et al., 2019)의 일부에 속한다. 화산 암류는 이전에 금호산화산암류로 묶어놓았지만(Kim and $\operatorname{Lim}, 1974)$ 분출암류와 관입암류로 쉽게 구분된다. 분출 암류는 하부의 안산암질암류와 상부의 유문암질암류로 구분된다. 안산암질암류는 김천단층(Kim et al., 1989) 남 부에 주로 분포하고 관입암류와 퇴적암류 사이에 소규모 로 분포한다. 이 안산암질암류는 안산암질 내지 데사이 트질 조성을 가지며 하부의 화성쇄설암과 상부의 용암으 로 구분된다. 하부의 화성쇄설암은 영암산응회암으로 하 고 상부의 용암은 부상리안산암으로 기재한다(Fig. 1). 상

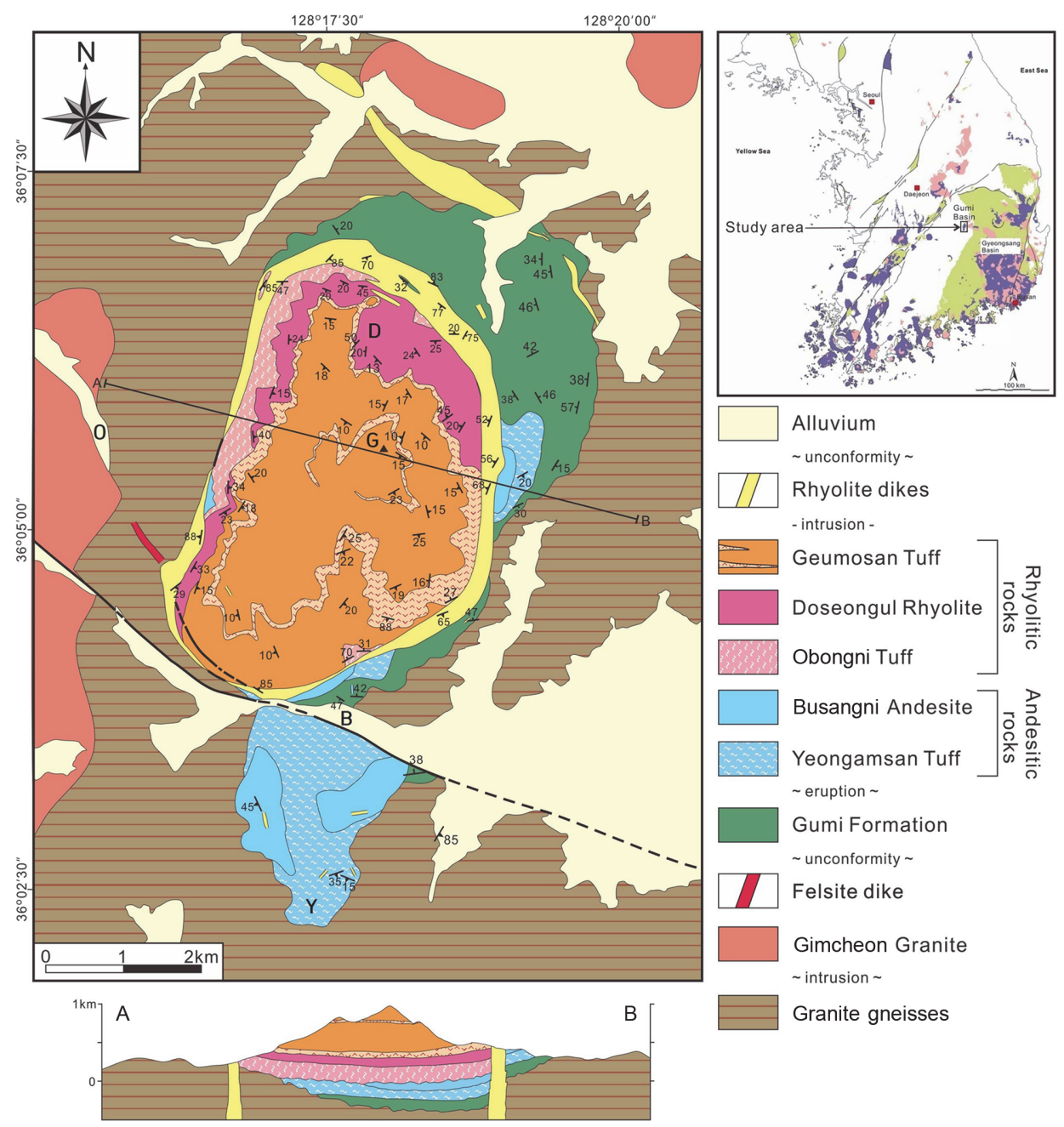

Fig. 1. Geologic map of the Gumi basin in mid-southeastern Yeongnam massif. The capital letters on the map represent major place names as follows: G, Geumosan; D, Doseongul; O, Obongni; B, Busangni; Y, Yeongamsan. 
부의 유문암류는 모두 유문암질 조성을 가지며 대부분 화성쇄설암으로 구성되지만 중간에 용암층이 협재되기 때문에 이를 기준으로 하부의 오봉리응회암, 중부의 도 선굴유문암과 상부의 금오산응회암으로 구분한다(Fig. 1). 관입암류는 유문암질 조성을 나타내는 세립질 맥암류 이며 환상암맥과 직선상암맥으로 산출된다. 특히 환상암 맥은 유문암질암류를 거의 완전히 둘러싸며 내측부에 상 위층이 외측부에 하위층이 분포하는 패턴을 나타내므로 확실한 함몰구조를 지시한다. 구미분지에서 발견되는 이 함몰구조를 우리는 금오산 칼데라로 지칭한다.

백악기의 모든 지층은 북서-남동 방향의 주향이동 단층 인 김천단층의 연장부에 의해 잘려 좌수향으로 어긋나 있다.

\section{3. 칼데라 이전의 백악기 지질}

구미분지에서 금오산 칼데라 이전에 형성된 지질은 크 게 구미층, 영암산응회암, 부상리안산암, 오봉리응회암과 도선굴유문암 순으로 구분된다.

\section{1. 구미층}

구미층은 환상암맥 밖에만 초승달 모양으로 소규모 분 포된다(Fig. 1). 화강편마암류 위를 부정합으로 덮고 용 암산응회암에 의해 덮이며(Fig. 2) 환상암맥에 의해 잘린 다. 두께는 최대 약 $300 \mathrm{~m}$ 로 추산된다.

이 층은 주로 녹회색 내지 회색의 사암, 역암과 셰일로 구성되는 것이 특징이지만 상부에서는 저색 사암과 이암 이 협재된다. 이러한 차이는 층서적으로 다른 층으로 구

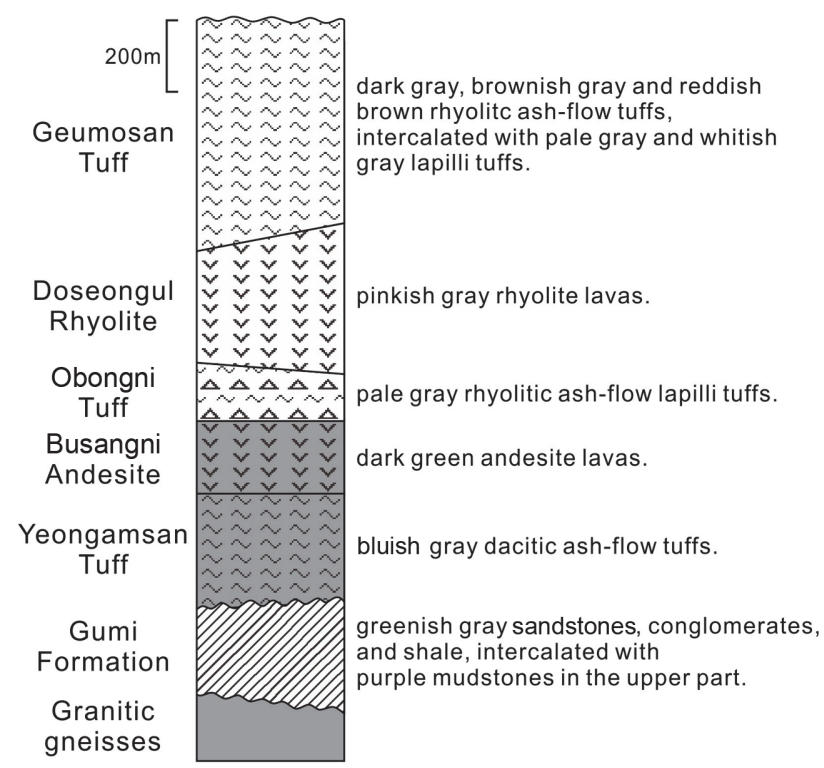

Fig. 2. Generalized vertical section showing the relationships of the broad lithostratigraphical divisions in the Gumi basin.
분될 수 있는 것인지 또한 경상분지의 낙동층 혹은 다른 층과 대비할 수 있는지는 앞으로 과제이다. 특히 역암은 대부분 편마암, 규암 등의 변성암 역들로 구성된다(Fig. 3a). 층리는 불규칙하지만 대체로 $20 \sim 57^{\circ}$ 내외로 화산암층의 중심을 향하여 경사진다.

\section{2. 영암산응회암}

영암산응회암은 환상암맥 밖에서만 산출되며 김천단층 남쪽에 크게 분포된다(Fig. 1). 이 층은 화강편마암류 혹 은 구미층을 덮고 부상리안산암에 의해 덮이며, 구미층 과는 부정합 관계를 나타낸다. 왜냐하면, 구미층 상부의 저색층이 영암산응회암 아래에서 산출되지 않고 잘리기 때문이다. 이 층의 두께는 김천단층 남쪽에서 최고 약 $300 \mathrm{~m}$ 이지만 지역에 따라 차이가 크다.

이 응회암은 청회색 내지 회색 기질에 결정이 비교적 풍부하고 종종 피아메(fiamme)와 암편을 함유한다(Fig. 3b). 결정은 대부분 $0.5 \mathrm{~mm}$ 이하 크기의 사장석이고, 각섬석 및 흑운모 등을 포함한다. 피아메는 암청회색을 띠며 대 개 1:5 정도로 편평화된 작은 부석편이다. 암편은 암녹색 안산암과 청회색 사암 등이 흔하게 관찰되고 그 직경은 흔히 $1 \mathrm{~cm}$ 이하이지만 $3 \mathrm{~cm}$ 도 있다. 이 응회암암층의 하 부에서는 대체로 암편이 많아지고 커져 라필리응회암에 속하고 $5 \sim 10 \mathrm{~cm}$ 크기의 암괴도 포함되어 응회각력암에 해당하는 부분도 있다.

이 암층은 전체적으로 괴상을 띠고 대부분 분급이 불 량하며 용결되어 드물게 용결엽리를 보여주기도 한다. 조 성은 대체로 안산암질 양상을 보여주지만 화학분석치에 서 데사이트질을 나타낸다. 따라서 이 암상은 낮은 분연 주 붕괴로부터 발생한 화쇄류에 의해 정치된 것으로 해 석된다.

\section{3. 부상리안산암}

부상리안산암은 환상암맥 외측부에서 영암산응회암 위 를 덮고 있으며 환상암맥 내측부에서 오봉리응회암 아래 에 아주 소규모로 노출된다(Fig. 1). 따라서 이러한 분포 패턴에 의하면 기하학적 관계는 안산암질암류가 유문암 질암류보다 선기 분출암이라는 것을 지시한다. 이 안산 암의 두께는 김천단층 남쪽에서 최고 약 $200 \mathrm{~m}$ 정도이 지만 측방변화가 매우 심하다.

노두에서 대부분 암녹색 내지 청회색을 띠지만 풍화가 진행된 곳에서는 국부적으로 암갈색을 띠고, 특히 대부 분 $1 \mathrm{~mm}$ 이하 크기의 사장석 반정에 의한 반상조직을 나타낸다(Fig. 3c). 서쪽 환상암맥 내측부와 남쪽 환상암 맥 외측부에서는 방해석과 녹니석으로 농집된 행인상 구 조를 관찰할 수 있다(Fig. $3 \mathrm{~d}$ ). 한편 드물지만 단암질 각 

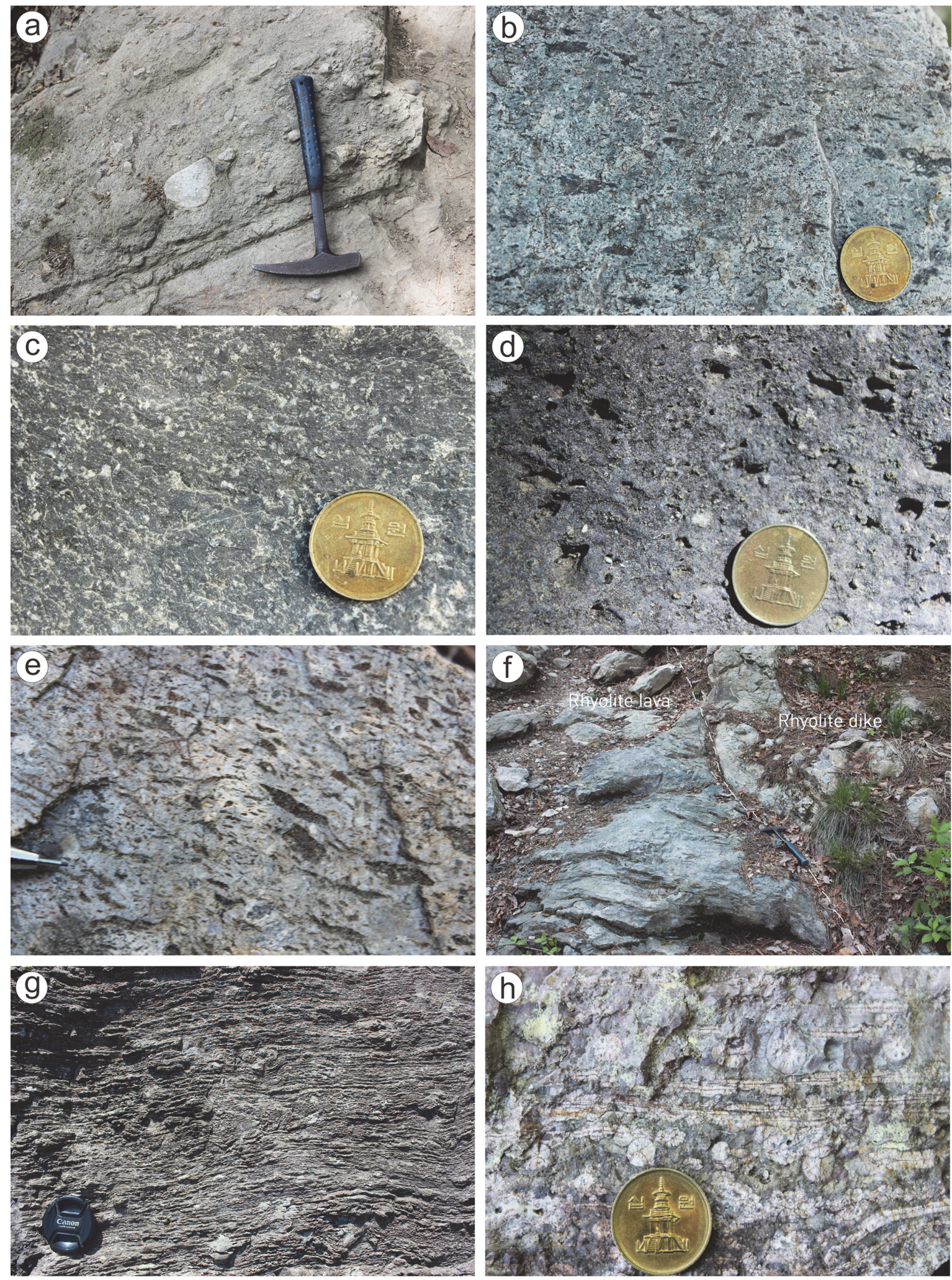

Fig. 3. Features of major outcrops in the Gumi basin. (a) Conglomerate in the lower part of the Gumi Formation; (b) Massive bluish gray ash-flow tuff with dark green fiammes in the Yeongamsan Tuff; (c) Porphyritic texture of the Busangni Andesite; (d) Amygdaloidal texture of the Busangni Andesite; (e) Massive pale gray ash-flow tuff with dark gray fiammes in the Obongni Tuff; (f) Doseongul Rhyolite lava intruded by a rhyolite dike; (g) Doseongul Rhyolite showing well developed flow foliation; (h) Spherulites and lithiphysae in the Doseongul Rhyolite, cutting the flow foliation. 
력암(monolithic breccia)이 용암의 흐름단위(flow unit) 사 이에 관찰된다. 경하에서도 대부분 뚜렷한 반상조직을 나 타내며, 사장석을 다량 함유하고 소량의 각섬석을 포함한다.

\section{4. 오봉리응회암}

오봉리응회암은 환상암맥 내측부에서 이 암맥을 따라 산록에 소규모로 분포한다(Fig. 1). 부상리안산암 위에 놓 이고 도선굴유문암에 의해 덮이지만(Fig. 2) 환상암맥에 의해 잘린다. 두께는 약 $150 \mathrm{~m}$ 이상으로 추산된다.

이 응회암은 담회색 내지 담녹색을 띠는 화산회 기질 에 암편과 부석을 함유하고 결정을 거의 볼 수 없다. 암 편은 암녹색, 암갈색 안산암이 흔하며 대개 1 3 cm (최 대 $5 \mathrm{~cm}$ ) 직경을 가진다. 부석은 대개 1:6으로 편평화되 고 최대 $5 \times 3.5 \mathrm{~cm}$ 크기를 가지며, 규칙적인 배열로 완배 열상(eutaxitic) 용결엽리를 나타낸다(Fig. 3e). 입도에 의 하면 대부분 라필리응회암에 속하며 분급이 불량하고 층 리도 나타나지 않으며 부분용결의 회류응회암에 속한다. 그러나 최상부 약 $15 \mathrm{~m}$ 가량은 입도가 훨씬 작고 층리 가 발달하는 층상응회암을 나타낸다. 그리고 이 응회암 은 두꺼운 환상암맥 접촉부에서 탈파리화되어 원래의 유 백색으로 탈색되어 유문암으로 오인될 수 있는 곳도 있다. 이러한 특징에서 회류응회암은 비교적 낮은 분연주 붕 괴에 의한 화쇄류에 의해 정치된 것이고 층상응회암은 분연주의 플룸으로부터 혹은 화쇄류의 재구름으로부터 나온 화산회 낙하에 의한 강하응회암에 해당된다.

\section{5. 도선굴유문암}

도선굴유문암은 환상암맥 내측부에서 현저한 절벽을 형성하면서 용암류(lava flow)로 산출되며 환상암맥을 따 라 대상으로 길게 분포한다(Fig. 1). 이 용암류는 오봉리 응회암 위에 놓이고 금오산응회암에 의해 덮이며(Fig. 2), 암맥에 의해 절단된다(Fig. $3 f)$. 이는 북동부 계곡의 횡단 면에서 최대 약 $350 \mathrm{~m}$ 로서 가장 두껍고 남서쪽으로 갈 수록 얇아진다. 전체적으로 이 용암류는 북동부 계곡에 서 산복부를 점령하지만 남서쪽으로 가면서 산록부에서 노출되고 남동쪽에서 지표에 노출되지 않는다.

이 유문암은 거의 모두 용암류로 구성되지만, 매우 드 물게 금오산의 북쪽 능선에서 암회색 부석을 갖는 유백 색 라필리응회암을 얇게 협재한다. 용암류 기저부는 특 히 단일 암괴들로 각력화되어 있는데, 이는 흐를 때 표 피와 내부의 냉각속도 차이로 발생하는 자동각력작용 (autobrecciation)에 의해 형성된 흐름 각력암으로 해석된다.

이 용암은 도홍색 내지 홍회색을 띠지만 기저부에서 담 청회색을 띠기도 하며, 반정을 볼 수 없는 비반상을 나 타낸다. 곳곳에서 $1 \sim 5 \mathrm{~mm}$ 내외의 유백색대와 홍회색대
가 조밀한 간격으로 반복되는 유상엽리(flow foliation)를 발달시킴으로써 유대상 유문암(flow-banded rhyolite)에 해당한다(Fig. 3g). 이 유상엽리는 간혹 유상습곡(flow fold)을 형성하고 자가포획체(autolith)를 함유하는데 드물 게 이들의 비대칭 패턴으로부터 이의 이동방향을 식별할 수도 있다. 그러나 유상엽리 속의 자가포획체는 가끔 렌 즈상을 이룸으로서 이 유문암을 평행배열상 석리(parataxitic fabric)를 갖는 치밀한 용결응회암으로 오인할 수도 있다. 그리고 상부에는 종종 구과상(spherulitic) 구조와 가끔 석 구상(lithophysal) 구조를 관찰할 수 있다(Fig. 3h). 구과는 흔히 2 3 mm 크기이고 최대 $1 \mathrm{~cm}$ 이며 유상엽리를 따라 배열되어있다, 석구는 $2 \times 5 \mathrm{~cm}$ (최대 $3 \times 6 \mathrm{~cm}$ ) 크기이고 그 중심에 $1 \times 2 \mathrm{~cm}$ 크기의 빈 공동을 가지며 흔히 석영 결 정이 자형으로 성장되어있다.

박편에서 이 용암은 석영과 장석의 미정질대와 미립의 불투명산화철 외에 결정화되지 않은 유리질대가 교호된다. 간혹 이들은 모자익상 결정질대 혹은 미구과상대와도 교 호된다. 유상엽리 즉 유백색대와 홍회색대의 색차이는 결 정도의 차이에 의해 정의되고 홍회색으로부터 회색으로 의 전이는 아마도 불투명산화철의 종류에 따라 달라진다.

결론적으로 유상엽리는 용암류가 층류로 이동할 때 속 도차이에 의해 나타나는 층류의 흔적으로 해석되며, 마 찬가지로 각력암은 용암류가 이동할 때 전단작용을 받아 냉각차이로 먼저 굳은 외피의 전단변형 흔적으로 해석된다.

\section{4. 칼데라 관련 백악기 지질}

구미분지에서 금오산 칼데라에 직접 관련된 지질은 금 오산응회암과 유문암맥 등이 있다.

\section{1. 금오산응회암}

금오산응회암은 이 지역에서 칼데라 형성에 직접적으 로 관련 되는 층서단위로서 환상암맥 내측부에서 도선굴 유문암 위를 덮으면서 넓게 분포한다(Fig. 1). 그리고 이 암층의 일부는 남서부에서 환상암맥에 의해 관입된다. 두 께는 최고 약 $600 \mathrm{~m}$ 로 계산된다.

이 응회암은 화학성분상 $\mathrm{SiO}_{2}$ 가 거의 전부 $72 ~ 76 \mathrm{wt} . \%$ 범위에 있다. 이 암층은 대부분 용결응회암으로 구성되 지만 중부 및 상부에 부분용결대가 두 차례 협재됨으로 해서 이를 사이에 두고 하·중·상부 치밀용결대로 구분된다.

(1) 하부 치밀용결대

하부 치밀용결대는 칼데라 내부의 남서부에 분포되며, 대부분 도선굴유문암 위를 덮지만 오봉리응회암 위를 덮 는 곳도 있다(Fig. 1). 

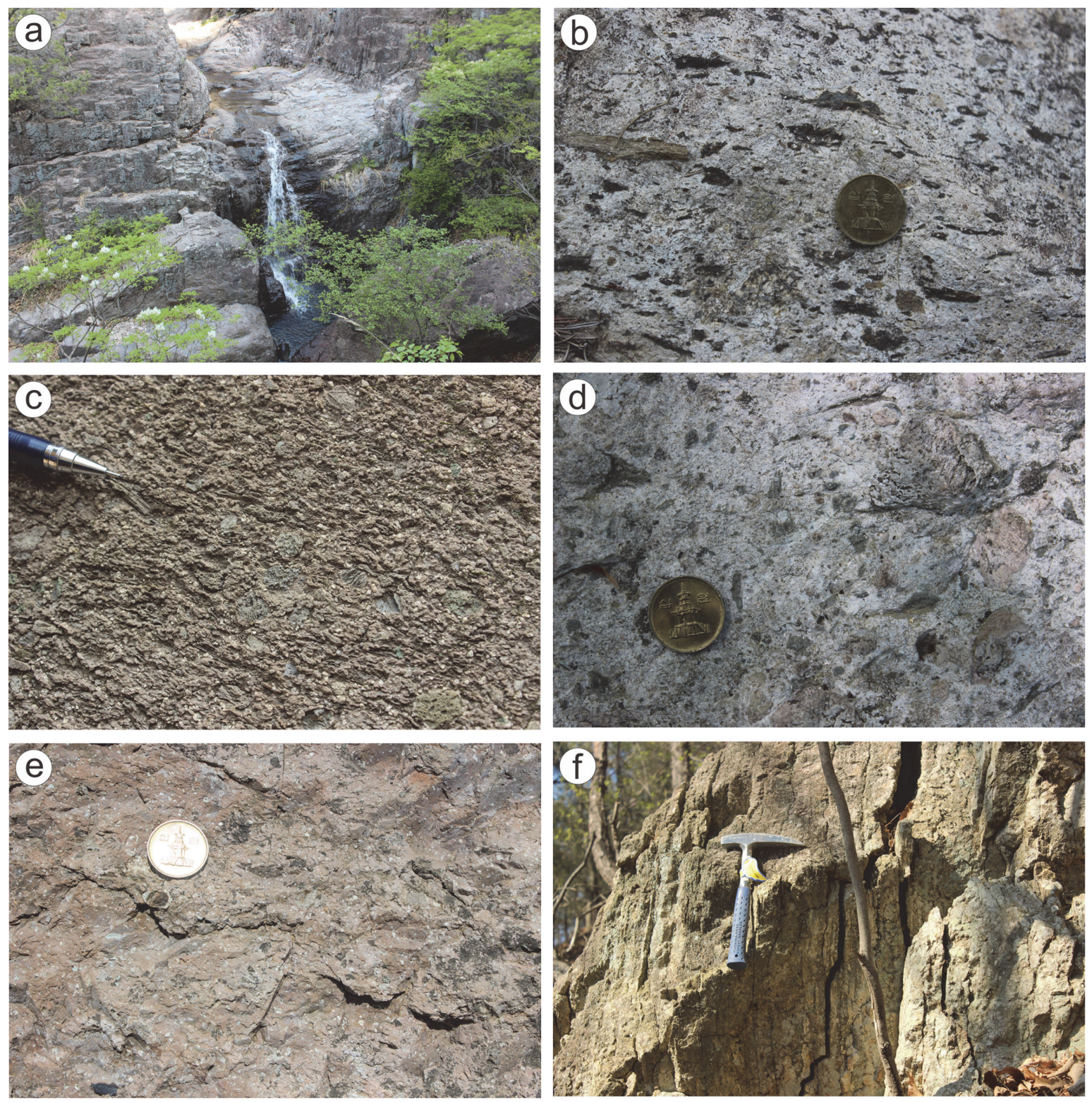

Fig. 4. Features of major outcrops related to the Geumosan caldera. (a) Dark gray, lower dense welding zone in the Geumosan Tuff; (b) Pale gray, middle partial welding zone in the Geumosan Tuff; (c) Brownish gray, middle dense welding zone in the Geumosan Tuff; (d) Whitish gray, upper partial welding zone in the Geumosan Tuff; (e) Reddish brown, upper dense welding zone in the Geumosan Tuff; (f) Outward-dipping subvertical flow foliation in the rhyolite ring dike.

하부 치밀용결대는 대체로 결정, 부석과 암편을 비교적 많이 함유하고 화산회가 풍부한 파리질 응회암에 속한다. 기질은 대체로 암회색 내지 회색을 띠는 것이 특징적이 고 부분적으로 산화작용에 의해 갈회색을 띠는 곳도 있 다(Fig. $4 \mathrm{a}$ ). 부석은 $3 \times 20 \mathrm{~mm}$ 로 편평화되고 용결된 암회 색 피아메로 존재한다. 결정은 $1 \mathrm{~mm}$ 이하 크기이고 대 부분 사장석이고 간혹 석영도 포함된다. 암편들은 대부 분 $1 \mathrm{~cm}$ 내외 크기의 담홍색 비반상 유문암편으로 구성 되고 1 3 cm 크기의 녹회색 비반상 안산암편도 포함된 다. 이 암편들은 대체로 크기와 함량이 하부로 갈수록 풍
부하며, 또한 특히 각 흐름단위의 그 기저에서 풍부하게 나타난다. 이러한 하부 치밀용결대는 회류응회암에 해당된다.

\section{(2) 중부 부분용결대}

중부 부분용결대는 금오산의 산복(山腹)에서 산출되며 칼데라 내부의 남부에서 하부 치밀용결대 위를 피복하거 나 혹은 북부에서 도선굴유문암 위를 덮는다(Fig. 1). 두 께는 대체로 $50 \mathrm{~m}$ 내외로 상당히 두껍지만, 동쪽으로 가 면 더 두꺼워져 최대 약 $150 \mathrm{~m}$ 이상에 달하는 곳도 있 고 서쪽으로 갈수록 $20 \mathrm{~m}$ 로 얇아지고 결국 치밀용결대 
로 대체되는 곳도 있다.

부분용결대는 대개 담회색을 띠고 부석과 암편이 풍부 하다(Fig. 4b). 부석은 암녹색을 띠며 다소 편평화되고 얼마 의 부석은 변형되어 불꽃같은 끝을 가진다(Fig. $4 \mathrm{~b})$. 샤아 드는 반정 혹은 암편 주위에서 변형작용에 의한 비대칭으 로 방향성을 나타내지만, 기질의 나머지는 주로 약간의 변 형만을 보여주는 임의 방향의 샤아드들을 포함한다. 암편 은 대개 회백색 유문암이며 1 2 $\mathrm{cm}$ 이고 최대 $4 \mathrm{~cm}$ 이다. 그러나 동쪽에서의 기저부는 큰 암편을 다량 함유하여 응회각력암에 속한다. 암편들은 암홍색 유대상 유문암으 로 구성되며 크기가 흔히 $3 \sim 5 \mathrm{~cm}$ 이고 최대 $13 \mathrm{~cm}$ 에 달한다.

(3) 중부 치밀용결대

중부 치밀용결대는 칼데라 내부의 금오산 산복에 분포 되며 중·상부 부분용결대에 의해 구분된다(Fig. 1).

이 치밀용결대는 대체로 암편을 적게 함유하고 부석과 결정을 비교적 많이 함유하며 화산회가 풍부한 파리질응 회암에 속한다. 그러나 이 용결대는 갈회색 내지 암갈색을 띰으로서 하부 치밀용결대에 비하여 붉은색을 띠는 것이 특징이며 암편이 드물고 그 크기가 작은 편이다(Fig. 4c). 부석들은 작지만 다소 풍부한 편이며 거의 모든 곳에서 치밀하게 용결되어 있고 대개 용결엽리를 나타낸다.

중부 치밀용결대에서 샤아드와 부석들은 하부 치밀용 결대보다 더 심하게 용결되어 있고 거의 모든 화성쇄설 조직이 파손될 정도로 강한 용결엽리를 형성하기도 하다. 그래서 이곳에서 부석은 누중에 의하기보다 높은 열과 흐름에 의해 매우 심하게 세장되고 편평화된 것으로 생 각된다. 왜냐하면, 이 치밀용결대는 하부 치밀용결대보다 하중을 훨씬 적게 받으면서도 더 심하게 용결되었기 때 문이다. 편평화된 피아메는 대부분 암회색이고 풍화면에 서 렌즈모양으로 튀어나온 예도 있다. 이들은 신선한 면 보다 약한 풍화면에서 더 뚜렷하게 인지된다. 왜냐하면, 피아메의 석기와 원래 응회암의 기질과는 쉽게 구별되지 않기 때문이다. 또한 반정은 하부 치밀용결대와 거의 대 등한 양으로 포함된다. 이와 같은 증거들은 이 용결대의 냉각시에 비교적 온도가 높았다는 것을 지지한다.

\section{(4) 상부 부분용결대}

상부 부분용결대는 금오산 산정부의 중·상부 치밀용결 대 사이에서 산출된다(Fig. 1). 두께는 대체로 $20 \mathrm{~m}$ 내외 로 비교적 얇은 편이다.

이 부분용결대는 대체로 회백색을 띠는 라필릴응회암으 로서 치밀용결대의 것보다 밝은색을 나타내는 것이 특징이 며(Fig. 4d), 비교적 약한 강도를 이용해 마애석불이 조각 되어있다. 부석은 흔하게 인지되며 담녹색을 띠고 $1 \mathrm{~cm}$ 내
외 크기가 흔하다. 암편은 회백색 유문암편이 다소 풍부 하며 드물게 암녹색 안산암편이 $1 \mathrm{~cm}$ 이하 크기로 존재한다.

(5) 상부 치밀용결대

상부 치밀용결대는 금오산 산정부를 차지하며 상부 부 분용결대 위를 덮는다(Fig. 1). 두께는 대략 $120 \mathrm{~m}$ 정도이다.

상부 치밀용결대는 대체로 부석과 결정을 적게 함유하고 화산회가 풍부한 파리질응회암에 속한다. 그러나 이 치밀 용결대는 적갈색 내지 암갈색을 띰으로서 중부 치밀용결 대보다 더 붉은색을 띠는 것이 특정이다(Fig. 4e). 부석들 은 드물고 그 크기가 작은 편이지만, 거의 모든 곳에서 치밀하게 용결되어 있고 대개 희미한 용결엽리를 나타낸다.

\section{2. 유문암맥}

유문암맥은 주로 칼데라 경계를 따라 환상암맥으로 산 출되고, 칼데라 외부의 북부에서 직선상암맥으로 산출된 다(Fig. 1). 두께는 10 450 m이고 모두 관입상을 나타낸 다. 구미층 퇴적암과의 접촉부에서 각력화된 곳도 발견된다.

이 암맥은 회백색 내지 유백색을 띠는 석정질 유문암 (stony rhyolite)으로 이루어지며, 이는 흔히 규장암으로 불리는 것이다. 대부분 괴상으로 나타나지만 연변부로 가 면서 희미하게 유상엽리가 고각도로 발달된다(Fig. 4f). 이 유문암은 전체적으로 반정은 거의 함유되지 않지만 매우 드물게 $1 \mathrm{~mm}$ 미만의 작은 사장석이 미반정으로 나 타난다. 경하에서 석기는 미정질 내지 은정질로 결정화 되어있으며, 특히 북부 직선상암맥은 미세한 미문상 조 직을 나타낸다.

이러한 유문암맥이 도선굴유문암을 관입한 곳에서는 색차이에 의해 구분되며, 유상엽리의 교차에 의해 더 확실 하게 입증된다(Fig. 3f). 이 암맥은 산출패턴과 위치에 따 라 환상암맥 아니면 칼데라 내부와 외부의 직선상암맥으 로 구분된다. 특히 북부의 두꺼운 곳에서의 환상암맥에는 저색 이암 혹은 라필리응회암이 그 유상엽리에 거의 평 행하게 기다란 포획체로 산출되고 있다(Fig. 1). 이와 같 은 유문암맥의 산출패턴과 결정도는 칼데라 함몰에 의한 환상단층을 따라 유문암질 마그마가 관입되었음을 지시한다.

\section{5. 칼데라의 기하학적 규모}

구미분지에서 금오산 화산암류는 주로 단층, 관입과 침 식에 의해 큰 영향을 받았으며, 이들에 의해 기존 화산 구조가 수정되었다. 이 화산암류에서의 엽리측정과 경계 추적에 의해 칼데라의 기하학적 모습을 복원할 수 있다.

일반적으로 젊은 칼데라는 그 함몰체에 대한 정보를 알 아내기가 어렵지만, 침식된 칼데라는 노출된 함몰체와 관 
Table 1. Caldera elements and calculated volume for the Geumosan caldera

\begin{tabular}{|c|c|c|c|c|c|c|c|c|}
\hline \multirow{2}{*}{ Structures } & \multicolumn{4}{|c|}{ Length of ring dikes and faults(total $15.7 \mathrm{~km}$ ) } & \multirow{2}{*}{$\begin{array}{c}\text { Subsidence } \\
\text { depth }\end{array}$} & \multirow{2}{*}{$\begin{array}{l}\text { Caldera } \\
\text { diameter }\end{array}$} & \multirow{2}{*}{$\begin{array}{c}\text { Caldera } \\
\text { area }\end{array}$} & \multirow{2}{*}{$\begin{array}{c}\text { Eruption } \\
\text { volume }\end{array}$} \\
\hline & NE dike & $\mathrm{S}$ fault & SW dike & $\mathrm{W}$ fault & & & & \\
\hline Measuring values & $12.0 \mathrm{~km}$ & $0.2 \mathrm{~km}$ & $2.9 \mathrm{~km}$ & $0.6 \mathrm{~km}$ & $350 \sim 600 \mathrm{~m}$ & $3.5 \times 5.6 \mathrm{~km}$ & $19.6 \mathrm{~km}^{2}$ & $23.6 \mathrm{~km}^{3}$ \\
\hline
\end{tabular}

입체의 형태와 함몰에 관한 기하학적 관계로부터 정보를 상세히 추론해낼 수 있다. 금오산 칼데라는 대체로 환상 암맥과 단층을 따라 구조적 경계를 구획할 수 있다. 그 래서 칼데라 영역은 환상암맥의 중간선과 환상단층을 이 상적으로 연결할 때 그 내부로 정의된다. 칼데라 내부는 대부분 금오산응회암이 차지하며 북부와 서부에서 이 아 래에 오봉리응회암과 도선굴유문암이 차례로 놓이고 부 상리안산암이 약간 노출된다. 그리고 외연부를 따라 완 전한 환상암맥이 관입되어 있고 그 외부에 구미층, 영암 산응회암 및 부상리안산암이 산발적으로 분포한다.

\section{1. 환상암맥과 칼데라 모양}

금오산 칼데라 영역 둘레의 총길이가 $15.7 \mathrm{~km}$ 에 달한 다(Table 1). 이 둘레는 대부분 환상암맥으로 연결되지만, 서측부 단층과 남측부에서 단층으로 대체되므로 북동측 및 남서측 환상암맥으로 나뉜다(Fig. 1).

남서측 환상암맥은 칼데라 서측부에서 남서측으로 호 상으로 연장되며 $2.9 \mathrm{~km}$ 에 달한다. 이는 서측부에서 $\mathrm{N} 20^{\circ} \mathrm{E}$ 방향으로 약 $200 \mathrm{~m}$ 이던 것이 북쪽으로 가면서 $10 \mathrm{~m}$ 로 좁아지며, 남쪽으로 가면서 $\mathrm{N} 40^{\circ} \mathrm{W}$ 방향으로 휘어지고 점차 $10 \mathrm{~m}$ 로 얇아진다. 그런데 이 환상암맥은 중간부에 서 서쪽으로 볼록 나와 그 폭이 최대 $300 \mathrm{~m}$ 로 넓어져 큰 플러그 모양을 이룬다.

북동측 환상암맥은 북서측에서 북동측을 거쳐 남동측 으로 $12.0 \mathrm{~km}$ 의 호상으로 길게 연결된다. 맥폭은 북동측 에서 약 $450 \mathrm{~m}$ 로 두껍지만, 북서측과 동측부에서 $250 \mathrm{~m}$ 내외이고 서측부와 남동측으로 갈수록 점점 좁아지다가 결국 서측부와 남측부에서 $10 \mathrm{~m}$ 이하로 얇아진다. 따라 서 두 환상암맥은 금오산 칼데라의 경계를 확실하게 정 의해준다.

이 환상암맥에서 유상엽리는 다소 불규칙하지만 대체로 주향이 관입접촉부에 평행하고 외측으로 $65 \sim 88^{\circ}$ 로 경사지 거나 혹은 거의 수직이다(Fig. 4f). 따라서 이 암맥은 칼데 라 함몰로 생긴 틈에 의해 지배되었다는 것을 암시한다. 그러면 이 관입체는 이미 형성된 통로에 주입되는 허용식 관입(permissive intrusion)을 고려해야만 한다. 즉 칼데라 함몰에 따른 지붕의 침하로 마그마챔버에 미치는 압력증 가로 인해 이때 잔류마그마가 함몰로 생긴 고리상 틈인 칼데라-경계 단층을 따라 올라와 채워진 것으로 생각된다.

\section{2. 칼데라 면적과 침하심도}

칼데라 침하의 전체 부피는 정확히 판단하기가 사실상 불가능하거나 애매하다. 침하 전의 지표의 구성과 구조(화 산구조, 이전 칼데라 바닥 등)는 자연 그대로의 젊은 칼 데라에만 알려져 있기 때문이다. 대부분 칼데라는 분출 중에 함몰이 시작되기 때문에, 칼데라 내부 충전물은 칼 데라 과정에 대한 주요한 증거를 제공하며, 회류응회암 과 이에 협재된 칼데라-벽 슬라이드 각력암은 침하된 영 역 내에 수 $\mathrm{km}$ 두께까지 축적된다(Lipman, 1976). 따라 서 침식 칼데라에서 칼데라 내부 응회암과 슬라이드 각 력암의 분포와 용적은 침하의 시기와 기하학적 모양에 대한 중요한 증거를 제공한다.

구미층은 환상암맥을 사이에 두고 칼데라 외부에서만 분포하지 내부에서는 전혀 노출되지 않는다. 영암산응회 암과 부상리안산암도 마찬가지로 환상암맥을 사이에 두 고 대부분 칼데라 외부에 분포하지 내부에 거의 산출되 지 않으며, 오로지 후자의 상단이 약간 노출될 뿐이다. 그리고 도선굴유문암과 금오산응회암은 칼데라 내부에만 분포하고 외부에서 전혀 발견되지 않는다. 즉 하부 암층 들은 칼데라 외부에 분포하고 상부 암층은 모두 절대적 으로 칼데라 내부에만 분포하므로 상당한 함몰이 있음을 입증하고 있다. 이처럼 칼데라 내·외부에서 상·하부 암층 의 현저한 분포차이는 환상암맥의 내부가 큰 낙차로 침 하하였음을 강하게 지시한다.

금오산 칼데라 영역은 환상암맥 및 단층으로 구획되는 거의 타원상 구역을 말한다. 이 구역 내에서 가장 짧은 직경은 NWW-SEE 방향으로 $3.5 \mathrm{~km}$ 이고 이에 직각 방향 의 직경은 약 $5.6 \mathrm{~km}$ 이다. 따라서 금오산 칼데라의 면적 은 대략 $19.6 \mathrm{~km}^{2}$ 로 계산된다.

금오산 칼데라의 침하심도는 칼데라 내·외부에 동시에 분포하는 층서단위의 주향과 경사를 이용하여 그 두께를 계산한 뒤, 고도차를 고려하여 구할 수 있다. 이 침하심 도는 북측부에서 약 $350 \mathrm{~m}$ 이지만 남동측에서 약 $600 \mathrm{~m}$ 이다.

이 칼데라에서 분출된 금오산응회암의 용적은 알려진 칼데라의 경계 외측부에 퇴적물이 사실상 없고 광역 침 식량에 대한 불확실성 때문에 필연적으로 추정에 근거할 수밖에 없다. 그러나, 대략적인 추정치는 잘 연구된 회류 칼데라에 대한 지식을 바탕으로 가능한데, 단지 칼데라 내부의 충전 회류응회암이 보존되는 경우에만 가능하다 [예, Wilson, 2001; Lipman, 2007]. 금오산응회암의 칼데 
라내부 용적은 이의 두께와 칼데라 내의 면적으로부터 구할 수 있다. 즉 칼데라에 축적된 용적은 면적 $19.6 \mathrm{~km}^{2}$ 를 금오산응회암의 최고 두께 $600 \mathrm{~m}$ 로 곱하면 $11.8 \mathrm{~km}^{3}$ 이다. 이는 대체로 외류(outflow)와 같다고 보기 때문에 (Lipman, 1984) 총용적은 약 $23.6 \mathrm{~km}^{3}$ 정도로 추산된다.

그런데 칼데라 바닥은 내측경사 환상단층(Reynolds, 1956) 또는 기타 복잡한 기하학적 구조(Branney, 1995)의 영향으로 인해 침하 중에 자루모양으로 아래로 축 처져 있다. 그러한 칼데라에서 침하심도는 반드시 구조적 경 계로 가면서 감소한다. 따라서 하향자루의 존재는 최대 침하심도로 계산된 칼데라의 침하 부피를 축소시킬 것이 다. 그러므로 금오산 칼데라에서 실제적인 침하심도는 계 산치보다 훨씬 더 큰 것으로 보아야 한다.

\section{3. 비대칭 하향자루}

칼데라 외부에서 구미층은 층리가 불규칙하지만 전체 적으로 화산 중심지로 향하여 경사진다. 즉 북동부에선 불규칙하면서도 남서쪽으로 $20 \sim 57^{\circ}$ 범위로 경사지고 남 동부에선 대체로 북서쪽으로 $38 \sim 40^{\circ}$ 경사진다(Fig. 1).

칼데라 내부에서 응회암에서의 용결엽리와 용암에서의 유상엽리를 관찰하면 뚜렷한 사발과 같은 하향자루 형태 를 인지할 수 있다(Fig. 1). 이 주변부에서 주향은 대체로 칼데라 경계선을 따라 평행하며 경사는 $15 \sim 45^{\circ}$ 로서 안쪽 으로 경사지는 하향자루 형태를 나타낸다. 반면에 이보 다 더 안쪽의 중심부에서 주향은 다소 불규칙하지만 대 체로 $10 \sim 20^{\circ}$ 내외로 남쪽을 향하여 경사지며 남쪽으로 갈수록 경사가 다소 완만해진다. 또한 오봉리응회암과 도 선굴유문암이 칼데라 경계선을 따라 평행하게 대상으로 분포한다. 종합하면 이러한 태위와 분포는 대체로 칼데 라의 주변부에서 안쪽으로 향심경사되고 남북으로 향사 축을 가지는 기다란 하향자루 형태를 지시한다. 그리고 이 자루의 향사축은 남쪽으로 경사지는데, 이는 비대칭 함몰구조를 지시한다. 따라서 환상단층과 환상암맥으로 경계를 이루는 칼데라 내부의 하향자루는 경계 단층의 완전한 발달에 앞서 초기 침하동안 하향자루운동을 하였 다는 것을 의미한다(Branney, 1995).

칼데라 내부의 북서측에서는 오봉리응회암이 노출되고 그 기저부까지도 부상리안산암 위에 노출되지만 남동측 에서는 오봉리응회암이 오로지 계곡부에서 국지적으로 노출될 뿐이다. 또한 칼데라 내부에서 금오산응회암의 용 결엽리가 중앙부와 남부에서 남쪽으로 대체적인 축경사 를 나타낸다. 그러므로 금오산응회암은 전체적으로 북쪽 에서 남쪽으로 갈수록 두꺼워져 $600 \mathrm{~m}$ 이상의 두께를 나 타낸다. 이는 침하가 모든 곳에서 일어났지만 남측부에 서 더 컸었다는 것을 지시한다.
위의 함몰증거들과 남향 축경사는 금오산 칼데라의 구 조적 블록이 북측부에서보다 남측부에서 더 깊은 심도를 보이는 비대칭 양상을 나타낸다. 이 때문에 금오산 칼데 라는 기하학적으로 비대칭 피스톤 침하 칼데라임을 의미 한다. 이러한 기하학적인 비대칭 양상은 그 원인이 비대 칭 침하에 의한 것인지 아니면 함몰후의 비대칭 소생에 의한 것인지는 다음에서 토의한다.

\section{6. 토 의}

금오산 칼데라 내부 암석단위의 공간적 관계는 지질도 에서 제시되었고 구조관계는 앞에서 기술되었다. 칼데라 를 경계짓는 환상단층은 환상암맥으로 주입되어 금오산 칼데라의 범위를 한정시켜 준다. 칼데라 영역은 환상암 맥 안쪽으로 3 개의 유문암질 암층이 차지하고 있다. 금 오산 칼데라는 위에서 토의한 바와 같이 기하학적으로 비대칭 피스톤 침하 칼데라에 속한다.

\section{1. 칼데라 침하 방식}

칼데라 침하 유형은 피스톤(판), 하향자루, 뚜껑문, 조 각상 및 깔데기 침하 등의 5 개 기하학적 엔드멤버로 제 안되었고(Lipman, 1997), 이에 따라 기재되어왔다(Cole et al., 2005). 잘 연구된 칼데라들은 이러한 이상적인 엔 드멤버들의 중간 침하과정을 나타내는 경우가 많다. 즉 환상단층 칼데라는 하나 이상의 호상 경계 단층을 포함 하는 복잡한 경계를 가질 수 있으며, 힌지상 하향자루 경 계와 환상단층 모두는 뚜껑문 칼데라 침하에 연관되어있 고, 일부 환상단층 칼데라 내의 바닥은 마그마가 빠르게 분출되는 곳에서 자루화되거나 혹은 단층으로 잘려있다 (Lipman, 1984; Branney, 1995).

일반적으로 칼데라는 가파른 경사의 환상단층에 의해 경계를 이루며, 일관된 바닥의 피스톤 침하에 연관되어 있다고 오랫동안 인식되어왔다(Smith and Bailey, 1968). 이 칼데라들은 천부의 큰 마그마챔버로부터 발생한 대규 모 분출과 연관되어있다. 피스톤 침하는 칼데라 바닥의 직경이 이의 두께를 초과하기 때문에 판 침하(plate subsidence)라는 용어를 사용하기도 한다(Lipman, 1997). 대부분의 피스톤 침하 칼데라 내에서, 공급 마그마챔버 위의 침하된 지붕은 회류 분출과 함몰 후의 마그마작용 동안 차별이동으로 인해 다양하게 붕괴될 수도 있지만, 혼란스러운 조각상 침하를 일으키는 경우는 거의 없다. 또한 환상암맥은 깊이 침식된 피스톤 침하 칼데라에서 환상단층을 주입한 관입체로 오랫동안 인식되어 왔다 (Reynolds, 1956; Smith and Bailey, 1968).

이러한 환상단층은 록키산맥 남부에서 고신기의 Lake 
City, Silverton, Mount Aetna와 Grizzly Peak의 칼데라, 홀 로세 Crater Lake 칼데라, 플레이스토세 Kulshan 칼데라 등에서 수 $\mathrm{km}$ 수 $10 \mathrm{~km}$ 크기로 잘 드러난다(Steven and Lipman, 1976; Fridrich et al., 1991; Nelson et al., 1994; Hildreth,1996). 일본에서도 기하학적으로 비교 가능한 많 은 피스톤 침하 칼데라가 제 3 기 화산 지역에서 지질학적 인 매핑에 의해 환상단층 경계를 찾고 시추에 의해 확인 함으로서 인정되었다(Yamamoto, 1992; Otake et al., 1997). 이탈리아 중부에서 Latera 칼데라도, 함몰후 용암돔의 동 심원상 분포에 기초하여, 환상단층으로 경계되고 일관된 피스톤 침하를 수반한다고 해석되었다(Nappi et al., 1991). 한편 환상암맥은 고기 침식 칼데라에서 많이 발견되었다 (Smith and Bailey, 1968; Yun, 1988; Hwang and Kim, 1992, 1999; Hwang, 1998, 1999, 2002).

금오산 칼데라 영역은 환상암맥 및 단층으로 구획되는 $3.5 \times 5.6 \mathrm{~km}$ 크기의 타원형 구역을 말한다. 둘레의 총길 이가 $15.7 \mathrm{~km}$ 에 달하고 면적은 $19.6 \mathrm{~km}^{2}$ 이다(Table 1). 따라서 금오산 칼데라에서도 경계 단층이 거의 대부분 환상암맥을 잘 발달시키고 전체 침하량의 대부분을 수용 하고 있으므로 피스톤 침하 칼데라로 해석된다.

이에 부수적으로 하향자루가 환상단층 및 암맥에 의해 경계된 칼데라 내부에서 잘 나타난다. 이러한 칼데라 바 닥에서 접시모양의 구조는 환상단층을 따라 안쪽 경사에 의해(Reynolds, 1956), 경계 단층의 완전한 발달에 앞서 초기 침하동안 더 광범위한 하향자루운동에 의해(Branney, 1995; Acocella, 2007), 또는 일반적으로 천부의 큰 마그 마챔버 위에서 열적으로 약화된 얇은 지붕의 국부적 침 하로 인해 발생할 수 있다. 환상단층과 환상암맥으로 경 계를 이루는 칼데라 내부에서 하향자루는 양산 칼데라와 구암산 칼데라 (Hwang, 1999, 2002) 등에서도 기록되어 있다. 종합해 보면, 지금까지 금오산 칼데라에서 수집된 지질학적 자료는 전형적인 피스톤식 구조 위에 중첩되는 하향자루 구조를 드러낸다(Lipman, 1997; Cole et al., 2005).

\section{2. 침하 과정}

구미분지에서 1차 화산작용은 약 $75.3 \mathrm{Ma}$ 전에 분지 남부에서 안산산암질 내지 데사이트질 마그마로부터 폭 발성 분출이 시작되고 분류성 분출로 전환되었다(Fig. $5 \mathrm{a}$ ). 그리고 2차 화산작용은 약 $74.7 \mathrm{Ma}$ 전에 분지 중앙부에 서 유문암질 마그마로부터 폭발성 분출이 일어나 분류성 분출로 바뀌었다(Fig. 5b). 3차 화산작용은 같은 지역에 서 $74.2 \mathrm{Ma}$ 전에 유문암질 마그마로부터 대규모 폭발성 분출이 여러 차례 일어나 환상단열을 일으키고(Fig. 5c) 결국 금오산 칼데라 함몰을 발생시켰다(Fig. $5 \mathrm{~d}$ ).
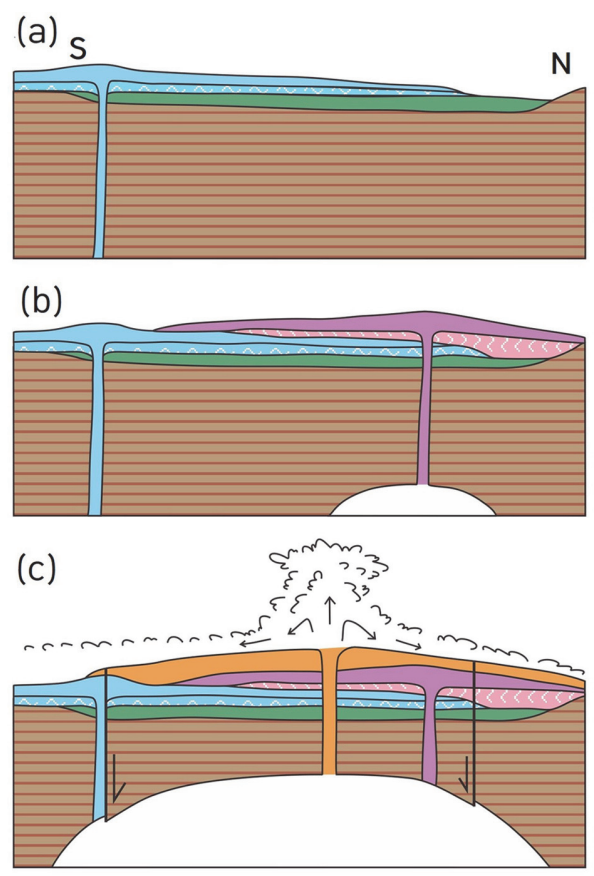

(d)
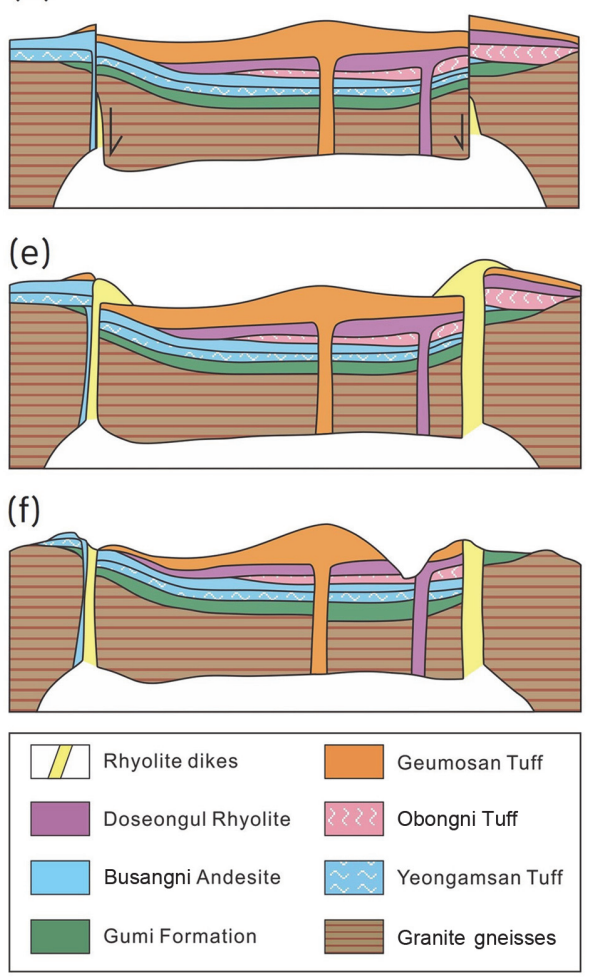

Fig. 5. Schematic sections showing the evolution of the Geumosan caldera. (a) First eruptions of pyroclastic flows and lavas from andesitic magma in the southern Gumi basin; (b) Second eruptions of pyroclastic flows and lavas from rhyolitic magma in the central Gumi basin; (c) Third eruptions of voluminous pyroclastic flows many times, followed by ring fractures in the same area; (d) Caldera collapse along the ring fractures and downsagging around them; (e) Magma injection along the ring faults; (f) Current surface exposed by erosion. 
칼데라 함몰에 관련된 암층은 화쇄류 형성 분출에 의 한 금오산응회암이다. 이때의 마그마 분출은 마그마챔버 의 압력을 점차 감소시키며, 마그마챔버 내의 감압 (underpressure)이 지붕 암석의 강도를 초과할 때 함몰이 일어난다. 금오산 지역에서 폭발성 분출로 마그마가 충 분하게 제거되면 챔버의 지붕이 갑자기 함몰됨으로서 침 하에 따라 금오산 칼데라가 형성되었다(Fig. $5 \mathrm{~d}$ ). 함몰은 하향자루운동과 환상단층운동이 결합된 방법에 의해 형 성되었을 것으로 생각된다. 이때 침하는 하향자루운동에 뒤따라 거의 동시에 시작되었을 것이고, 이와 함께 외측 경사 혹은 거의 수직으로 발달하는 환상단층을 따라 진 행되었을 것이다(Fig. 5 c). 환상단층을 야기할 수 있는 가 능한 기구는 마그마 상승으로 인한 지붕의 붕괴와 마그 마챔버의 파열 등이 포함될 것이다.

칼데라 함몰을 유도하는 일반적인 원인은 잘 이해되지 만, 칼데라가 어떻게 형성되는지는 별로 검토되지 않았 고 아마도 여러 칼데라 유형 간에 변화가 있을 것으로 보고 있다(Walker, 1984; Branney, 1995; Lipman, 1997). 칼데라의 함몰 방식은 새로운 화도의 개시를 제어할 수 있기 때문에 칼데라 형성 분출의 방출률과 역학에 중대 한 결과를 가져올 수 있을 것이다. 여러 경우에서 큰 부 피의 회류응회암은 환상열극을 따르는 분출에 의한 것으 로 제안되어 왔다(Druitt and Bacon, 1986; Hildreth and Mahood, 1986). 이들 경우에서 환상열극은 마그마의 주 요 화도로서 역할하는 경우가 많았다(Walker, 1984). 또 한 칼데라에 관련된 여러 회류응회암 중의 일부는 중앙 화구 분출에 의한 산물로 해석된 예도 있다(Walker, 1984; Aramaki, 1984; Suzuki-Kamata and Kamata, 1990). 따라 서 이는 아마도 칼데라 침하가 반드시 마그마의 화도로 서 환상열극의 역할을 의미하지 않는다는 것을 나타낸다.

초기 분출은 중앙화구로 시작되었지만 나중에 함몰이 본격적일 때 환상단열이 뒤따른다는 것은 여러 칼데라에서 이미 주장된 바 있다(Bacon, 1983; Hildreth and Mahood, 1986; Self et al., 1986, Hwang et al., 1997; Hwang, 2002). 금오산응회암의 중부 비용결대에서 암편이 풍부한 화쇄 류상은 흔히 방출률과 암편 함량의 증가를 의미하는데, 이는 새로운 화도의 개시 혹은 기존화도의 확대로 인해 대규모 모암의 빠른 침식이 있었음을 의미한다. 왜냐하 면 금오산 칼데라는 초기 중앙화구에서 후기 환상열극화 구로의 화구 이동이 있었다는 증거를 찾지 못했기 때문 이다. 다시 말한다면, 이 침식은 다른 화도의 개시보다도 차라리 기존화도의 확대에 그 원인이 있을 수 있다.

칼데라의 환상단층은 안으로 혹은 밖으로 경사지고 혹 은 수직일 수도 있다(Marti et al., 1994; Branney, 1995; Lipman, 1997; Gudmundsson, 1998). 내측경사 열극은 지
붕 함몰 시에 닫히게 되기 때문에 마그마 화도로서 열극 을 유지하기 위해서는 계속적인 침식이 요구되고 분출시 에 한때 화쇄류 속에 더 많은 암편 함량을 초래할 수밖 에 없을 것이다. 대조적으로 외측경사 열극은 지붕이 침 하될 때 화도침식 없이도 점차 열리게 된다. 외측경사에 서 화도는 지붕이 침하하는 동안 암편 침식 없이 점차 넓어진다면, 이는 화쇄류분출 동안에 점차 방출률 증가 를 초래하고 회류응회암에서 체계적인 역점이를 초래할 수도 있다. 이에 근거하면 금오산 칼데라에서 환상암맥 은 대체로 외측경사를 이루고 있기 때문에 환상열극 화 구로의 전이를 배제할 순 없는 것 같다. 이 외측경사 환 상열극는 칼데라블록이 침하될 동안에 암편 침식 없이도 점차 넓어질 것이며, 이때 분출은 점차 방출률 증가를 초 래하고 회류응회암에서 체계적인 역점이를 초래할 수 있 기 때문이다.

\section{3. 환상암맥의 정치}

칼데라함몰을 일으켰던 분출활동은 이후 마그마공급이 정지될 정도로 고갈되지 않고 칼데라후의 작은 마그마활 동을 유도할 수 있을 만큼 마그마챔버에 마그마가 풍부 하게 잔류되어 있었다. 대규모 분출로 인한 지붕의 침하 는 챔버의 상단에서의 정암압(lithostatic pressure)을 복구 하게 될 것이다. 이 마그마는 부력의 원인이 되는 마그 마 과압(overpressure)으로 인하여 환상단층 속으로 주입 이 일어나는데(Fig. 5e), 이 주입은 화도 침식 없이도 암 맥을 형성하게 된다(Gudmundsson et al., 1999). 그러나 한번 화도에 주입되면 마그마의 높은 속도와 점성이 화 도 내에 큰 마찰력을 감소시키게 된다(Papale, 1998). 이 는 마그마 압력이 화도의 대부분에 걸쳐서 정암압보다 더 작은 원인이 된다. 그러므로 마그마의 과압은 화도가 열려 있게 놓아두지 않고 침식이 일어나게 하지도 않는 다. 화도에서 감압은 실제로 화도의 침식을 촉진되게 한 다(Macedonio et al., 1994).

금오산 칼데라에서 환상단층도 역시 외측 혹은 수직으 로 경사졌을 것으로 밝혀졌다. 즉 환상암맥이 전 둘레에 걸쳐 거의 대부분 형성되어있을 뿐만 아니라, 유상엽리 가 대부분 수직 혹은 바깥으로 급경사되기 때문이다. 이 러한 외측경사는 맥폭이 대체로 200 450 m로 넓어진 원 인으로 생각된다. 왜냐하면, 열극의 폭은 하향자루운동으 로 넓어질 뿐만 아니라 외측경사 환상단층에서 지붕이 깊게 내려앉을수록 넓어지기 때문이다.

따라서 금오산 칼데라에서 암맥들의 위치와 모양에 의 하면 이들의 정치는 외측경사 환상단층에 의해 지배되었 음을 알 수 있다. 즉 칼데라 함몰후에 환상단층을 따라 유문암질 마그마가 관입되었다(Fig. 5e). 이후 챔버의 마 
그마가 비대칭 상승에 의해 지붕의 북변부가 동시에 상 승하게 되었던 것이다. 따라서 칼데라 블록은 이에 따른 침하심도의 수정으로 인하여 비대칭 구조를 이루게 되었 다. 즉 북변부에서 $350 \mathrm{~m}$ 인데 비하여 남변부에서 $600 \mathrm{~m}$ 를 이루는 침하심도의 비대칭은 마지막 마그마 상승에 따라 수정된 것이다.

환상암맥의 정치는 일반적으로 칼데라 내부와 함께 환 상단층에서 일어났던 함몰후 마그마활동의 표시이다(Smith and Bailey, 1968). 따라서 칼데라형성 분출에 관련되는 환상암맥은 조성상으로 회류응회암과 같을 것이다. 그래 서 금오산 칼데라에서 이들의 관계와 조성의 유사성에 비추어 볼 때, 금오산응회암의 회류응회암과 환상암맥 간 에 성인적으로 관련이 있음을 지시한다. 즉 금오산 칼데 라의 환상암맥은 이 칼데라 윤회에 시공간적으로 밀접히 조합되어 있는 마그마활동의 산물이며 아마도 침식 삭박 으로 없어진 화산도움들의 뿌리부분에 해당된다.

\section{7. 결 론}

구미분지는 백악기의 구미층 퇴적암류와 금오산화산암 류로 구성된다. 금오산화산암류는 하부 안산암질암류, 상 부 유문암질암류, 관입암류로 구분된다. 안산암질암류는 하부 영암산응회암과 상부 부상리안산암으로 구성되고, 유문암질암류는 하부 오봉리응회암, 중부 도선굴유문암 과 상부 금오산응회암으로 구성된다. 관입암류는 환상암 맥과 직선상 암맥으로 구분된다.

금오산응회암은 거의 대부분 회류응회암으로 구성되며 환상암맥과 함께 금오산 칼데라와 연관되어있다. 금오산 칼데라는 회류응회암-칼데라-환상암맥으로 연결되는 하 나의 칼데라 윤회를 나타낸다.

칼데라의 크기는 $3.5 \times 5.6 \mathrm{~km}$ 이고 면적은 대략 $19.6 \mathrm{~km}^{2}$ 로서 환상암맥과 단층으로 둘러싸인다. 칼데라 내부 화 산암층은 유상 및 용결엽리가 대체로 칼데라 연변부에서 안쪽으로 경사되는 하향자루 형태를 나타낸다. 칼데라 블 록은 북변부에서 $350 \mathrm{~m}$, 남변부에서 $600 \mathrm{~m}$ 내려앉은 비 대칭 침하를 나타낸다.

이 자료들에 의하면 금오산 칼데라는 하나의 칼데라윤 회를 따르는 기하학으로 비대칭 피스톤 침하 칼데라로 분류된다. 즉 챔버로부터 마그마의 대규모 분출에 뒤따 라 외측경사 환상단층으로 경계되는 칼데라 블록의 피스 톤 침하를 반영한다. 칼데라 블록에서 하향자루는 경계 단층의 완전한 발달과 동시에 초기 침하동안 하양자루운 동을 의미한다. 이 운동에 따라 벌어진 환상열극은 침하 에 따른 마그마 과압으로 인해 환상암맥을 주입시켰다.

\section{사 사}

이 연구는 한국지질자원연구원 기관고유사업인 국토지 질조사 및 지질도·지질주제도 발간(GP2020-003)의 일환 으로 수행되었다. 이 논문의 심사과정을 통하여 유익한 지적과 건설적인 비평을 해주신 두 익명의 심사위원님께 사의를 표한다. 그림 제작은 안동대학교 화산실험실 현 혜원의 도움이 있었다.

\section{References}

Acocella, V. (2007) Understanding caldera structure and development: An overview of analogue models compared to natural calderas. Earth-Science Reviews, v.85, p.125-160.

Aramaki, S. (1984) Formation of the Aira caldera, southern Kyushu, 22,000 years ago. J. Geophys. Res., v.89, p.8485-8501.

Bacon, C.R. (1983) Eruptive history of Mount Mazama and Crater Lake caldera, Cascade Range, U.S.A. J. Volcanol. Geotherm. Res., v.18, p.57-115.

Branney, M.J. (1995) Downsag and extension at calderas: new perspectives on collapse geometries from ice-melt, mining, and volcanic subsidence. Bull. Volcanol., v.57, p.303-318.

Cole, J.W., Milner, D.M. and Spinks, K.D. (2005). Calderas and caldera structures: a review. Earth Sci. Reviews, v.69, p.1-96.

Druitt, T.H. and Bacon, C.R. (1986) Lithic breccia and ignimbrite erupted during the collapse of Crater Lake caldera, Oregon. J. Volcanol. Geotherm. Res., v.29, p.1-32.

Fridrich, C.J., Smith, R.P., DeWitt, E. and McKee, E.H. (1991) Structural, eruptive, and intrusive evolution of the Grizzly Peak caldera, Sawatch Range, Colorado. Geol. Soc. Am. Bull., v.103, p.1160-1177.

Gudmundsson, A. (1998) Formation and development of normalfault calderas and the initiation of large explosive eruptions. Bulletin of Volcanology, 60, 160-170.

Gudmundsson, A., Marinoni, L.B. and Marti, J. (1999) Injection and arrest of dykes: implications for volcanic hazards. J. Volcanol. Geotherm. Res., v.88, p.1-13.

Hildreth, W. (1996) Kulshan caldera: A Quaternary subglacial caldera in the North Cascades, Washington. Geol. Soc. Am. Bull., v.108, p.786-793.

Hildreth, W. and Mahood, G.A. (1986) Ring-fracture eruption of the Bishop Tuff. Geol. Soc. Am. Bul., v.97, p.396-403.

Hwang, S.K. (1998) Evolution and type of the Wondong caldera, western Yangsan. J. Geol. Soc. Korea, v.34, p.20-32 (in Korean with English abstract).

Hwang, S.K. (1999) Type and evolution of the Samrangjin caldera, southern Miryang. J. Geol. Soc. Korea, v.35, p.19-32 (in Korean with English abstract).

Hwang, S.K. (2002) Collapse type and evolution of the Guamsan caldera, southeastern Cheongsong, Korea. J. Geol. Soc. Korea, v.38, p.199-216 (in Korean with English abstract). 
Hwang, S.K. and Kim, S.W. (1992) Sillicic volcanism of Yangsan Caldera, Korea. J. Geol. Soc. Korea, v.28, p.445-458 (in Korean with English abstract).

Hwang, S.K. and Kim, S.K. (1999) Type and evolution of the Myeonbongsan caldera. J. Petrol. Soc. Korea, v.8, p.171-182 (in Korean with English abstract).

Hwang, S.K., Kim, S.W., Kee, W.-S. and Kim, J.J. (2019) U-Pb zircon ages and division of the Cretaceous volcanic arc in the Korean Peninsula: Spatiotemporal evolution of the arc volcanism. J. Geol. Soc. Korea, v.55, p.595-619 (in Korean with English abstract).

Hwang, S.K., Lee, G.-D., Kim, S.W. and Lee, Y.J. (1997) Volcanisms and volcanic processes of the Wondong caldera. J. Petrol. Soc. Korea, v.6, p.96-110 (in Korean with English abstract).

Kim, J.H. and Lim, J.W. (1974) Explanatory text of the geologic map of Gumi Sheet. Daejon, Geological and Mineral Institute of Korea, 20p.

Kim, S.W., Yang, S.Y. and Lee, Y.J. (1989) Geological report of the Gimcheon Sheet. Daejon, Geological and Mineral Institute of Korea, 22p.

Lipman, P.W. (1976) Caldera collapse breccias in the western San Juan Mountains, Colorado. Geological Society of America Bulletin, v.87, p.1397-1410.

Lipman, P.W. (1984) Roots of ash-flow calderas in western North America: windows into the tops of granitic batholiths. J. Geophys. Res.., v.89, p.8801-8841.

Lipman, P.W. (1997) Subsidence of ash-flow calderas: relation to caldera size and magma-chamber geometry. Bull. Volcanol., v.59, p.198-218.

Lipman, P.W. (2007) Incremental assembly and prolonged consolidation of Cordilleran magma chambers: Evidence from the Southern Rocky Mountain volcanic field. Geosphere, v.3, p.42-70, doi:10.1130/GES00061.1.

Macdonald, G.A. (1972) Volcanoes. Prentice Hall, New Jersey, 510p.

Macedonio, G., Dobran, F. and Neri, A. (1994) Erosion processes in volcanic conduits and an applications to the AD 79 eruption of Vesuvius, Earth Planet. Sci. Lett., v.121, p.137-152.

Marti, J., Ablay, G.J., Redshaw, L.T. and Sparks, R.S.J. (1994) Experimental studies of collapse calderas. J. Geol. Soc. London, v.151, p.919-929.

Nappi, G., Renzulli, A., Santi, P. (1991) Evidence of incremental growth in the Vulsinian calderas (central Italy). J. Volcanol.
Geotherm. Res., v.47, p.13-31.

Nelson, C.H., Bacon, C.R., Robinson, S.W., Adam, D.P., Bradbury, J.P., Barber, J.H., Schwartz, D., Vagenas, G. (1994) The Volcanic, sedimentologic, and paleolimnologic history of the Crater Lake caldera floor, Oregon. Evidence for small caldera evolution. Geol. Soc. Am. Bull., v.106, p.684-704.

Otake, M., Sato, H. and Yamaguch, Y. (1997) Geologic development of the Late Miocene Tokusa caldera in the southern Aizu district, northeast Honshu, Japan. J. Geol. Soc. Japan, v.103, p.1-20 (in Japanese, with English abstract).

Papale, P. (1998) Volcanic conduit dynamics, in: A. Freundt and M, Rosi (eds.), From Magma to Tephra: Modelling Physical Processes of Explosive Volcanic Eruptions, Elsevier, Amsterdam, p.55-89.

Reynolds, D.L. (1956) Calderas and ring complexes. Verh K Ned Geol Mijnbouwkd Genoot, v.16, p.355-398.

Self, S., Goff, F., Gardner, J.N., Wright, J.V. and Kite, W.M. (1986) Explosive rhyolitic volcanism in the Jemez Mountains: Vent locations, caldera development, and relation to regional structure. J. Geophys. Res., v.91, p.1779-1798.

Smith, R.L. and Bailey, R.A. (1968) Resurgent cauldrons. Geol. Soc. Am. Memoir v.116, p.613-662.

Steven, T.A. and Lipman, P.W. (1976) Calderas of the San Juan volcanic field, southwestern Colorado. US Geol. Surv. Prof. Pap., p.958, p.1-35.

Suzuki-Kamata, K. and Kamata, H. (1990) The proximal facies of the Tosu pyroclastic flow deposit erupted from Aso caldera, Japan. Bull. Volcanol., v.52, p.325-333.

Walker, G.P.L. (1984) Downsag calderas, ring faults, caldera sizes, and incremental caldera growth. J. Geophys. Res., v.89, p.84078416.

Williams, H. and McBirney, A.R. (1979) Volcanology. Freeman, Cooper and Co, San Francisco, 397p.

Wilson, C.J.N. (2001) The 26.5 ka Oruanui eruption, New Zealand: An introduction and overview. J. Volcanol. Geotherm. Res., v.112, p.133-174, doi:10.1016/S0377-0273(01)00239-6.

Yamamoto, T. (1992) Chronology of the late Miocene-Pleistocene caldera volcanoes in the Aizu district, northeast Japan. J. Geol. Soc. Japan, v.98, p.21-38 (in Japanese, with English abstract).

Yun, S.H. (1988) Development and the Structure of Its Cauldron of the Hwasan Ring Igneous Complex, Northern Kyeongsang Basin, Korea. J. Geol. Soc. Korea, v.24, p.267-288 (in Korean with English abstract). 